\title{
A Profession Turned Upside Down - And Couldn't Be Happier!
}

\author{
Stephen Joel Trachtenberg
}

Historical perspective is something to which we all pay tribute - perhaps in order to hold off our feelings of amazement and possible upset. Is there anything more remarkable, after all, than the miracles of growth and decline, upheaval and reversal and transformation, brought about by the passage of time?

Such has certainly been the case where the field of public administration is concemed. In 1959, for example, as I entered my senior year in college, and thought I might eventually want to work in government, I asked a wise and respected administrator at Columbia College - Larry Chamberlain - whether he would advise me to go on for a law degree or for a Master's in Public Administration.

Larry gave the matter some serious thought and then opted for the former alternative. The MPA was too new and untested, he felt. A law degree would give me more professional leverage and flexibility. And since most of those currently working in government positions were lawyers themselves, it would also function as a "union card" of sorts. I'd be, in effect, a member of the club.

In today's world, I suspect, Larry's answer would be the other way around. Public administration has come of age. The ability to function well in government is no longer regarded as a form of on-the-job training that can be added to some other credential. Even the general public is aware of the sheer amount of grueling staff work that lies behind the public announcements of a Bill Clinton, a Ted Kennedy, a Bob Dole, or any federal agency. Government has become too complex and pervasive and multi-layered to be other than a full-time profession.

This doesn't mean, of course, that we don't sometimes find ourselves longing for the simplicities of an earlier age. American politics would be incomplete without regular denunciations at election time of govemment "bureaucracy" - a term so often used in ways that translate into government itself. Indeed, sentiments like these have helped to mandate the current round of budgetary cutbacks in the federal government, at least some of which will be seen in retrospect as administratively unwise.

As products of our own cultural heritage, we never cease to hanker for the American frontier, where small and functional governments were ostensibly set up to deal with real and immediate problems. The appeal of a classic film like Shane is that it professes to deal with an even earlier moment, when the free and expressive use of "the land out there" began to give way to fences and registered property and taxes - what most of us now regard as the proper concerns of government - including courts of law whose tedious "bureaucratic" processes were designed to offer a reasonable chance of justice.

\begin{tabular}{c} 
"As products of our own cultural \\
beritage, we never cease to banker \\
for the American frontier, where \\
small and functional governments \\
were ostensibly set up to deal with \\
real and immediate problems." \\
\hline \hline
\end{tabular}

Shane, you might say, embodies what Americans have sometimes seen as the tragedy of public administration the loss, through "bureaucracy," of some vital original condition in which social issues were settled on an impromptu basis, by the "ultimate reality" of physical force. In the 1990s, though, we're most likely to respond, when watching the film, to one particular part of the cattle baron's angry self-defense - the moment when he refers 
to "a Cheyenne arrow" as one of the problems he had to deal with in his conquest of the land, a problem roughly on a level with limited water supplies and poor grazing.

Having learned many lessons in recent decades, we are likely to ask: "Who was the member of the Cheyenne national group who shot that arrow? How did be feel about the occupation - for purposes of either cattle-grazing or farming - of what had been, until then, his land? What happened to bim?" And if the rancher's rhetoric effectively dehumanizes that person, if it implies that 'Cheyennes' are as interchangeable (to our eyes) as what were once called 'lesser mammals', then what does that tell us about the America that drove so relentlessly toward and beyond its western ocean?

It's time, in other words, for us to acknowledge that the rise of public administration as a discipline has coincided with the flowering of our concern with human justice. A concern like this has inevitably made our lives more complicated and has closed us off from earlier patterns of simple and mutual hatred. When a version of our past appears today - in Bosnia, or in a film like Schindler's List - we recoil in horror. Suddenly, in the starkest possible way, we recognize the extent of our present social cushioning, the faith that there are public procedures for dealing with virtually any private feeling - administrative procedures that allow for reconsideration and, if necessary, for an appeal to a court of law. When a natural disaster occurs in our land, an earthquake or hurricane, all of our longings for primal simplicity evaporate and the cries go up: "Where are the public administrators? Why isn't the government providing more relief? There ought to be an investigation!"

In a slow and uneven way, therefore - because that's how the human mind so typically works - the past three decades have seen not only the rise of public administration as a discipline but the internalizing, by the vast majority of us most of the time, of what you might call a public administrator metaphor. When we think of the human world today - at the municipal, regional, national, and even global level - we reflexively think of collective administrative arrangements, adaptable to the solving of all kinds of human problems and social challenges.

Put yourself back only a short time in history, and you will find yourself in a world where the last question most people asked when a war broke out somewhere was: "What went wrong?" The underlying conviction was that things were always going wrong and that wars were only amazing when they were temporarily absent. Come back to 1994 , and you will find yourself at a point in human history when conflict, destruction and injustice have come to be perceived as "problems" - implicitly, as soluble problems. What we now have that would have seemed bizarre to our ancestors is the pervasive sense that "things can be worked out" using administrative procedures established even in the face of deep hatred and long-standing grievance.

\begin{tabular}{c}
\hline "It's time . . \\
to acknowledge that \\
the rise of public \\
administration as a discipline \\
bas coincided with the \\
flowering of our concern \\
with buman justice."
\end{tabular}

Among other things, that new faith helps to account for the dramatic change that has taken place in our financial behaviors. Americans are routinely sending billions of their hard-earned dollars abroad via a new galaxy of mutual funds, despite the routine wamings those funds issue about the risks of political instability and social upheaval in the lands where they buy stocks and shares. What Americans are voting for, with those hard-earned dollars, is the conviction that even in other cultures, many of which still fall short of being what we would recognize as liberal democracies, the choice of an administrative over an adversary metaphor has been and is being made. An internationally shared style of government which seeks to minimize the disruption caused by political change is the basis for an internationally shared system of capital investment. And more and more residents of our planet are capable of empathizing with the content of one of GW's public administration courses: Dynamics of Citizen Participation in Administration.

Thus, Amèricans watch with understandable fascination as the Mexico into which they have poured so much capital begins the awesomely difficult administrative reforms - the wrenching governmental readjustment called for by violent upheaval and perceived injustice. Political intention, we are reminded once again, can only be realized through a system of pervasive practice. As is suggested by another $\mathrm{GW}$ public administration course, Ethics and Public Values, public officials can, by shared "misunderstanding" of public law, systematically undermine its intentions. 
The arrival of public administration at the core of our shared assumptions about government makes the appearance of this journal a very timely event. It also leads me to think about some of the directions in which our discipline may be moving in the years ahead.

One of these directions will surely be international and will probably take a relatively "hands-on" form. Those of us who have been following the national policy debates of recent months - especially those dealing with health and unemployment - may have been struck by the old ways in which we still depend on occasional newspaper and magazine articles for our understanding of how other nations deal with exactly parallel challenges. The Canadian system of national health, for example, moves in and out of our own discussions on this subject, always in a fashion charged with ideology. "It's great and worthy of emulation!" one voice cries. "It's nowhere near as good as our own system and its costs are spiraling up-" ward!" an equally loud voice replies. What's missing? An ongoing forum, co-sponsored by GW and McGill University, perhaps, in which officials from both systems meet to compare notes with each other and with their European counterparts.

Or take one of our grimmest new clichés: that the employment crisis we are experiencing here in the United States is in fact international and represents a global rush toward "downsizing" (also known, somewhat ominously, as "enhanced productivity"). The rise of planetary unemployment may represent the other face of what Francis Fukuyama sees as the coming triumph of capitalist liberal democracy. It represents a structural challenge with which no nation can deal on an isolated basis. And what's needed, therefore? An ongoing international symposium, perhaps, in which ministries and departments of finance and labor routinely meet to discuss the strategies that can help us deal with the spectre of joblessness - including. the strategy known as free and untrammeled labor markets.

Finally, I believe it's time that we started to discuss the possible need for a new and somewhat higher degree in public administration - a doctorate that emphasizes practice more than theory. Perhaps such a degree could be seen in a context closely related to the international forums I have just tried to envision. Imagine if public administrators drawn from around the globe, with at least five or ten years of practical experience, could be enrolled in a doctoral program whose "dissertations" take the form of current working papers on specific national and international problems - papers that are no sooner complete than they are transmitted, electronically or in printed form, to the agencies across the globe that are dealing with identical or closely related challenges.

Our field is growing. It is a firmly rooted discipline. Policy Perspectives: The George Wasbington University Journal of Public Administration symbolizes its vigor and its professional appeal. Let us make' certain that we keep growing with it!

Stephen Joel Trachtenberg is President of The George Washington University and Professor of Public Administration. * 